\title{
A Summary of the Parliamentary and Presidential Elections in Mozambique, 1999
}

\author{
By \\ Vicky da Silva \\ Vicky da Silva is an Information Officer at the Electoral Institute of Southern Africa, PO Box 740, \\ Auckland Park, 2095, South Africa; \\ Tel: +27 11482 5495; Fax: 482 6163; e-mail vdasilva@eisa.org.za
}

The 1994 and 1999 presidential and parliamentary elections were widely hailed as a vote for peace. They were also seen as a test of electoral management, being held in the wake of the failure of the 1998 local government elections. Those elections were boycotted by the opposition parties who alleged that the national elections committee, the Comissâo Nacional de Eleicôes (CNE) and the Technical Secretariat for Election Administration (STAE) were partial to Frente de Libertaçâo de Moçambique (Frelimo). Only Frelimo and four groups of independent citizens in Maputo, Beira, Nacala and Manhiça took part in the local government elections.

The staging of well-run elections, and gaining acceptance of the results are often separate issues. Mozambique is a case in point, with the legitimacy of its recent commitment to multiparty elections hinging on all parties recognising the election results. One of the key mechanisms to achieving this acceptance of election results is to ensure that the body administering the elections operates in a transparent and accountable manner. Even the suspicion or allegation of wrongdoing, well founded or not, can be sufficient to derail an electoral process.

\section{Political Background}

In 1990, under the auspices of the religious mediators from Sant Egidio in Rome, Frelimo and the Resistência Nacional de Moçambique (Renamo) began a series of negotiations. In October 1992, Frelimo and Renamo signed the Rome General Peace Accord and ended the 16-year civil war.

On 27-29 October 1994, Mozambique held its first multi-party presidential and parliamentary elections. Frelimo's Mr Joaquim Alberto Chissano won the presidential election in the first round with 53.3\% of the total votes cast. His rival Mr Afonso Macacho Marceta Dhlakama of Renamo obtained 33.3\% of the vote. The election for the 250-member Parliament was also won by Frelimo with $44.3 \%$ of the vote, followed by Renamo with a strong showing of $37.8 \%$. The Democratic Union (UD), a coalition of three parties, obtained little more than the national threshold of $5 \%$ of the total votes cast required to enter Parliament. The remaining $13 \%$ repre sented the total votes won by the other parties, which had failed to obtain the required minimum of $5 \%$. These votes were redistributed among the winners. Their respective percentages changed as follows: Frelimo moved to 51\% (129 parliamentary seats) Renamo increased its share to 44\% (112 parliamentary seats) and the UD maintained its $5.15 \%$ share (9 parliamentary seats).

An analysis of the results in terms of party strength by province shows that Frelimo secured a majority of votes in six of the 11 electoral constituencies, namely, Maputo City, 
Maputo Province, Gaza, Inhambane, Niassa and Cabo Delgado. Renamo was the majority party in the remaining five provinces of Manica, Nampula, Sofala, Tete and Zambezia.

A request by Renamo to be assigned the governorships of the five provinces where it secured a majority of the votes in the parliamentary election was rejected by Chissano. Instead, he appointed new governors in several provinces, all of whom were Frelimo members. Moreover, all the portfolios in the new national government were assigned to Frelimo members.

The first local government elections were held in June 1998 after several postponements. Poor organisation, a boycott by Renamo and 15 smaller parties, and the electorate's lack of confidence in the electoral machinery obstructed the elections. The result was a voter turnout of only $15 \%$. This lack of participation stimulated key political actors and other electoral role-players in Mozambique, and the international community, to become more involved in the running of the 1999 presidential and parliamentary elections.

There were three electoral coalitions: the Democratic Union, the Mozambican Union (Umo) and the Alliance for Democracy (APD). There were a number of small parties that had not joined any of these coalitions, namely, the Labour Party (PT), the United Democratic Front (UDF) and the Independent Party of Mozambique (Pimo). The two major political parties were the ruling Frelimo and the main opposition party, Renamo.

On 16 July 1999, Renamo entered into an electoral alliance with 10 smaller political parties, despite its public announcements in March 1999 that it would not enter into any such arrangements following failed negotiations with several parties. This coalition was known as Renamo Electoral Union (UE), and Renamo was undoubtedly the main partner. Renamo-UE endorsed Afonso Dhlakama as its presidential candidate. All coalition members used the flag and symbols of Renamo in their electoral campaigning in exchange for the inclusion of their leaders in Renamo's parliamentary electoral lists.

\section{The Electoral System}

The Mozambican electoral system for parliamentary elections is a party-list proportional representation one. There are 11 constituencies, corresponding to the ten provinces in the country and the city of Maputo. These constituencies send between 13 and 50 representatives to the Assembly of the Republic (AR) (Parliament) based on the number of registered voters.

In the case of the presidential election, article 111 of the Electoral Law states that the winner must obtain more than a half of the valid votes, including the null and void votes.

The Supreme Court acts as the Constitutional Court and, therefore, has authority over all electoral disputes.

In late March 1999, a new national electoral commission, Comissâo Nacional de Eleicôes (CNE), was established to supervise the second multiparty presidential and parliamentary elections. Seventeen members comprise the commission - two appointed by the government, eight by Frelimo, six by Renamo and one by the UD. The Reverend Jamisse Taimo, a Methodist pastor and rector of the Higher Institute for International Relations, was appointed chairperson of the 1999 CNE. In late March 1999, Antonio Carrasco was appointed as the new director general of the STAE.

The 1999 Electoral Law provides for greater transparency by ensuring that every aspect of the electoral process can be monitored. The inclusion of party representatives in the CNE and STAE at national, provincial, and district levels has created more confidence in the electoral 
machinery. There are provincial CNEs with six members appointed proportionally by political parties to their respective parliamentary representations and one by government. At the district level, there are four members nominated by their political parties in proportion to their seats in Parliament and one by government. During the registration and election periods, the two largest parties, namely, Frelimo and Renamo, name deputy director generals to STAE, nationally and locally.

\section{Election Preparations}

\section{Voter Registration}

Because the local government elections lacked legitimacy, the 1998 electoral roll was discarded and voter registration was started anew. It was held between 20 July and 17 September 1999, in compliance with the legal requirement that it take place over 60 days. In 1996, the total population of Mozambique was estimated at 18.2 million inhabitants and the voting population was assumed to be approximately 8.3 million. A total of 7099105 people registered for the 1999 elections (85.5\% of the eligible population) compared to 6.1 million people (78\%) in the 1994 elections. This increase in registration figures affected the numbers of parliamentary seats allocated to each province.

The registration exercise was observed by 3520 local observers from the Forum for Civic Education (Fòrum de Educaçâo Civica) (Feciv) and the Mozambican Association for Democratic Development (Associaçâo Moçambicana para Desenvolvimento da Democracia (Amode). International observers, from institutions such as the US-based Carter Center and the Electoral Institute of Southern Africa (EISA), also observed the registration process. There were 1930 registration posts countrywide, of which 1902 (98.5\%) began work on the first day of registration. The remaining registration posts were in operation within the first week of the process. In addition, a number of mobile posts enabled voters who lived in remote and sparsely populated rural areas to register.

However, the registration process faced a number of problems, such as:

- many people had to walk long distances to reach the registration posts in order to register;

- the inadequate road infrastructure which made the delivery of registration material difficult;

- registration material shortages at a number of posts;

- ineffective communication between registration posts and the STAE;

- the supply of food to and payment of the electoral staff was delayed at certain posts;

- electoral authorities did not issue letters of accreditation timeously to the local observers from FECIV, AMODE and various church groups; and

- Renamo representatives were included in the provincial and district STAE only towards the end of the registration process.

International observer missions and local observers, however, declared that there was no systematic occurrence of the above problems and in most cases, the registration staff effectively managed the issues that arose. Moreover, Renamo, which had alleged that false identity documents were issued to Malawians, South Africans, Tanzanians and Zimbabweans, failed to substantiate its claims. 


\section{Registration of Political Parties and Candidates}

The registration of political parties, coalitions of parties and individual candidates took place between 15 and 30 September 1999. The following parties and coalitions were confirmed by the CNE as having fulfilled all the legal requirements to stand for the National Assembly election after a number of party splits, floor crossings, and the formation and collapse of electoral alliances:

- Independent Party of Mozambique (Pimo);

- Liberal Party of Mozambique (Palmo);

- Freedom Front of Mozambique (Frelimo);

- Labour Party (PT);

- Green Party of Mozambique (PVM);

- Democratic Party of Mozambique (Padelimo);

- Party for Liberal Progress of Mozambique (PPLM);

- Liberal Social Party (Sol);

- Partido Nacional dos Operários e Camponeses (Panacoa);

- Partido de Ampliaçao Social e Soberenia de Moçambique (Pasomo);

- Democratic Union (UD);

- Democratic Union of the Opposition (Umo); and

- Renamo-Electoral Union (Renamo-UE).

Candidate nominations were preceded by intra-party elections. Frelimo and Renamo organised primary elections in each of the provinces and produced their party lists for the National Assembly elections. These primary elections were an opportunity for the party provincial structures to reward or punish representatives according to their perceived performance from 1994 to 1999. Mr Manuel da Fonseca and Mr Jafar Gulamo Jafar, two Renamo Members of Parliament failed to maintain their positions as heads of the party lists in their respective provinces.

Renamo did not have a policy to ensure a fair representation of women and other marginalised groups. This resulted in the party having very few female candidates. In addition, Renamo failed to have a single woman heading any of its 11 lists.

In contrast, Frelimo had a clear policy in this regard. In fact, the ruling party's policy about the selection of candidates requires that one-third of candidates are women, one-fifth are youths and one-tenth former liberation fighters. In addition, the ranking of these candidates was done in such a way that their respective positions on the electoral list did not compromise the required levels of their representation. As a result of this policy, Frelimo had a fair representation of women on its lists and there were several cases of women heading their party list, such as Ms Veronica Macamo in Gaza and Ms Margarida Talapa in Niassa.

\section{Presidential Candidate Nominations}

Whereas in 199412 candidates stood for the presidential election, the 1999 presidential election had only two candidates. The CNE extended the deadline for the submission of nomination papers from Saturday, 9 October to Monday, 11 October 1999, as the Supreme Court is closed over the weekend. When nominations closed only three applications were accepted, namely, Chissano of Frelimo, Dhlakama of Renamo and Mr Yá-Qub Sibindy of Pimo. The court rejected the other three applicants, Mr Wehia Ripua of Umo, Mr Joachim Nyota of Padelimo and Mr Armando Siueia of Panacoa. The identity cards submitted by Sibindy's supporters were rejected on the grounds of signature irregularities. Sibindy was thus forced to withdraw from the presidential race, as the majority of the signatures supporting his presidential 
candidature came from Angoche in the northern province of Nampula and it would be impossible to amend the irregularities within the five days granted him by the court. Thus, only Chissano and Dhlakama qualified to stand for the 1999 presidential election.

\section{Voter Education}

There is NGO involvement in voter education but it could be improved on. In 1999, three of the international NGOs that had actively supported civic education in 1994, the National Democratic Institute (NDI), European Parliamentarians for Southern Africa (AWEPA), and the Frederich Ebert Foundation, withdrew their support. A study done in 1999 by the Centre of Studies on Democracy and Development (CEDE) a recently created organisation led by the 1994 CNE president, Dr Brazao Mazula, revealed that these international organisations not only financed most of the NGOs but also controlled the conception of programmes, the strategies involved and their general execution.

The 1999 elections demonstrated that, although the overwhelming majority of voters were aware of the dates of registration and polling, many still had difficulties following the voting procedures and did not yet understand the meaning of the elections in the national political system. The involvement of more NGOs in voter education over a longer period could serve to popularise many aspects of the electoral process, such as the procedures of registration and voting. There is still a lot to do regarding NGO involvement in voter education, to ensure that such work is more effective, efficient and lasting.

\section{Public Funding of Political Parties}

Approximately US\$2 million was made available for the electoral campaigns of contesting political parties. USAID contributed US\$500 000; the Mozambican government, US\$480 000; Sweden, US\$470 000; the Netherlands, US\$340 000 and Switzerland, US\$100 000. The funds were equally allocated between the presidential parties, the parties represented in Parliament in proportion to the number of parliamentary seats, and the other contesting parties in proportion to the number of candidatures filled for the National Assembly election.

Parties received an initial payment and then subsequent instalments only when they had accounted for the expenditure of the preceding instalment. This was done in order to avoid the irregularities and abuses that had occurred in 1994 when a number of political parties failed to provide the CNE with documentation to justify their use of public funds. The new regulation led to several opposition parties accusing the CNE of purposefully delaying the release of funds to the advantage of the ruling party.

\section{Cost of the Elections}

The budgeted cost of the 1999 Mozambican presidential and parliamentary elections amounted to US\$40.8 million. The Mozambique government provided US\$8.8 million while the European Union contributed US\$22 million and the UNDP US\$10 million.

\section{The Electoral Campaign}

The electoral campaign took place from 19 October to 30 November 1999. Frelimo and Renamo dominated the campaign period. One of the consequences of this political polarisation was the increase of mutual hostility between members and supporters of the two parties.

Renamo began its campaign in the districts of Majacaze, Chibuto and Chokwe, the birthplaces of Frelimo's presidents, Mr Eduardo Mondlane, Mr Samora Machel and Chissano. This 
was followed by an outbreak of violent incidents including confrontations, beatings and the use of firearms. Many locals accused the police of standing by and watching the Chokwe violence unfold. In Changara, Tete province, Frelimo supporters burnt down the house of the Renamo representative after a Renamo rally was held in the area. The two parties accused each other of inciting the violence.

The Manica campaign was strongly contested, with Renamo and Frelimo criticising one another. Renamo used the threat to return to civil war and both parties often relied on insulting language in campaign speeches and songs.

Given the prevalence of transport difficulties in Sofala province, offers of bicycles were used as a means of winning over potential party activists during the election campaign. As in other provinces, both parties waged vigorous campaigns, relying on party songs, door-to-door campaigns, rallies and processions to improve party visibility.

\section{The Media}

Local and international observers praised the media for its contribution to raising awareness of the elections. Radio Mozambique and Television of Mozambique (TVM) gave continuous summaries and updates on the activities of the electoral candidates and the election campaigns as a whole. Both corporations seemed to provide balanced electoral news. In addition, Radio Mozambique had set up a code of conduct for its reporters. However, several other media houses were accused of biased coverage of electoral matters. The excessively partisan character of the newspapers was notorious. The daily Noticias and the weekly Domingo were reportedly more favourable to Frelimo and Imparcial to Renamo. In its assessment of the campaign, the Carter Center found that 'coverage of confrontations between supporters of Renamo and Frelimo has been one-sided and often inflammatory'.

\section{Election Observers}

\section{National Observers}

In provinces where NGO forums existed associations were set up for observation purposes. In addition, individuals also took it upon themselves to partake in the observation process. The national observation programme, however, was primarily organised by two NGOs, the Forum for Civic Education (Feciv) and the Association for the Development of Democracy (Amode). They deployed almost 1000 observers throughout the country. The Christian Council of Mozambique (CCM), which consists of the main churches and Protestant institutions, deployed 514 observers. One group of individuals defined itself as 'thirty-seven Mozambican citizens, individually and independently, duly accredited by the competent organisations of the electoral administration, conscientious of their civic responsibilities'. It included people such as Mr Teodoreo Waty, the president of the Municipal Assembly for Maputo City, Mr Magid Ossman, president of the Council of Administration of BCI and Professor Dr Lourenco de Rosario, Rector of the Istituto Superior Politechnico e Universitario. Another such group was the Associacao Mulheres, Lei e Desenvolvimento Amuleide in Sofala province. A team of 14 observers worked in Dondo, Buzi and Nhamatanda. This was the first time Mozambican organisations and individuals took part in the observation of elections in their own country.

\section{International Observers}

The Carter Center sent two observation missions to Mozambique, one to observe the registration process and another to observe the voting. A delegation of 50 observers, 
representing 16 countries, led by former presidents Mr Jimmy Carter and Mr Ket Masire observed the voting period of the elections. On the polling days, these observers visited 649 voting stations spread across almost 50 districts in all 11 provinces of the country.

The electoral observation mission sent by the European Union was composed of 64 observers from 12 countries. They visited almost 750 voting assemblies in 34 districts throughout the country. They reported 'very few problems or breaches of the electoral rules' and that 'none of those had an impact on the results'.

The Commonwealth, as well as the CPLP, organised small observation missions that expressed satisfaction at the behaviour of the voters and the manner in which the electoral process had been conducted.

The Southern Africa Development Community Electoral Commissions Forum (SADC ECF) sent a delegation of eight observers and associated researchers, led by Justice L M Makame, the forum's president, to Mozambique for the electoral period. The goal of this mission was to identify those aspects of the electoral process that could be improved upon in future elections and to make recommendations to the Mozambican authorities. The ECF delegation observed the elections in Tete, Zambezia, Nampula, Cabo Delgado, Maputo Province and Maputo City and stated that 'the elections themselves were conducted in a peaceful atmosphere and in a satisfactory fashion'.

International observers from the Organisation for African Unity (OAU), the SADC Parliamentary Forum and other international bodies were also present for the elections.

\section{The Poll}

Between 3 - 5 December 1999, Mozambicans went to the poll for the second time. Voters arrived early at the stations and waited patiently in the queues. National and international observers reported that there appeared to be a strong commitment to abiding to the electoral rules and procedures by polling staff, party agents and voters.

The CNE extended polling by one day as heavy rains and poor infrastructure delayed the delivery of voting materials to many polling stations. The Electoral Law does not allow the CNE to extend voting time to individual parts of the country. Thus, when it became evident that further opportunities to vote were needed in the areas where the voting could not be carried out timeously, the CNE had to extend the process to the entire country. It was generally felt that the third day had been unnecessary in most of the voting districts, with the exception of those areas where materials had arrived late. In some voting districts, the number of voters on the third day did not reach double digits. According to the reports, most of those who appeared at the voting stations on the third day were those citizens who had been prevented from voting earlier for various reasons such as employment commitments or ill health. Electoral staff who had not been posted to their own registration stations were allowed to leave their posts to cast their votes. It appears that a partial extension would have been preferable, given the costs involved.

A fundamental rule of the Mozambican electoral process, and one that guarantees transparency, is that the counting of votes begins immediately at the close of the poll. A partial extension raises the problem of the results from some polling stations being displayed, and probably announced by the media, while at other polling stations voters would still be casting their votes or waiting to do so. The alternative to this scenario would be to begin the counting only when all the votes had been cast nation-wide. However, this delay could compromise transparency of the process. 
The election results for the parliamentary elections in Nampula were close, with Renamo gaining close to $43 \%$ of the vote and Frelimo 39\%. Nampula province has the largest number of voters in the country and therefore was allocated 50 seats, the highest number of any province. At the provincial level, Dhlakama won considerably more of the presidential votes (57\%) than his rival Chissano (43\%).

Over the three days there was a voter turnout of $70 \%$, which was a clear demonstration of Mozambicans' commitment to, and belief in, the electoral process. Although the 1994 elections had a voter turnout of $88 \%$, many more Mozambican citizens were directly involved in the 1999 election as observers and electoral officials.

A number of problems, however, were reported, such as:

- errors in the completion of voters' cards during the registration process that prevented the voters from being able to cast their votes. This problem could have been avoided if the voters had checked their names during the period when the electoral lists were displayed for this purpose;

- incidents of violence between Frelimo and Renamo supporters during the electoral campaign. Renamo claimed it was prevented from campaigning in the districts of Changar, Cahora Bassa and Mague in the Tete Province;

- failure of the police to restore order;

- late delivery of voting materials to certain polling stations in Nampula province (Nacarroa, Muecate and Erati), in Gaza province (Macandazulo), in Manica province (Chinete and Zembe) and in Sofala (Marromeu, Chibabava and Gorongoza). The main cause for late delivery of the voting materials was the poor state of the road network in the countryside;

- voting did not take place at all at the eight polling stations in the district of Pebane, Zambezia, owing to technical and communication problems caused by heavy rains and a helicopter crash. This affected approximately 8000 voters;

- difficulties in controlling the queues (sometimes of thousands of voters), especially on the first day of voting;

- inadequate lighting at the polling stations, especially at closing and in the rural areas, which, combined with the fact that voting took place over three days, may have contributed to the number of errors made in the filling out of registers;

- the size of the polling stations was so small that the secrecy of the vote was compromised;

- proximity of police officers at certain polling stations to the polling booths or not maintaining the distance recommended by the Electoral Law; and

- insufficient security guards to watch the election materials overnight at several polling stations. In addition, there were no Renamo party agents to monitor the voting and counting in the entire Changara district in Tete province.

\section{The Results}

The final results were released by the CNE on 22 December 1999 after a delay owing to technical problems. This delay caused anxiety and contributed to rising tensions within the country.

Chissano was re-elected President of the Republic with 52.3\% of the votes, against $47.7 \%$ for Dhlakama. The ruling party consolidated its parliamentary majority by obtaining $48.5 \%$ of the vote against Renamo-UE's 38.8\%. 
In terms of overall representation Renamo, which secured 112 seats in the 1994 Parliament, increased its representation to 117 seats, of which only 100 were from the party, the remainder being distributed among its coalition partners. The votes gathered by the smaller parties that could not reach the minimum requirement of $5 \%$, totalled $12.8 \%$. This was slightly higher than the total of $11.68 \%$ reached in the 1994 elections. This increase in percentage was one of the reasons the smaller parties were prepared to enter into a coalition with Renamo. The coalition was mutually beneficial as it allowed the candidates from the smaller opposition parties to be elected and, consequently, Renamo boosted its representation in the legislature.

The distribution of votes in the 1999 elections repeated the pattern of the 1994 elections. Frelimo retained a majority of the seats in the southern half of Mozambique as well as Cabo Delgado and Nampula in the north. Renamo retained its strongholds in the central provinces. (see table below). The country is in fact polarised into areas of support for the two major political parties.

Representation in the national assembly is based on the results of 11 provincial elections. Because of proportional representation, regional electoral strength plays a significant role in a party's electoral success. The provinces of Nampula, Zambezia and Cabo Delgado have the most registered voters, thus they have the most national assembly seats assigned to them. Based on the distribution of votes in the 1999 elections, Mozambique can now be described as a two-party electoral system, with support for the parties rooted in their regional strongholds.

\begin{tabular}{lcc}
\multicolumn{2}{c}{$\begin{array}{c}\text { Mozambique } 2000 \\
\text { Elections: Provincial } \\
\text { Assembly Seats }\end{array}$} & Distribution of National \\
& Frelimo & $\begin{array}{c}\text { Renamo-Electoral } \\
\text { Union }\end{array}$ \\
Niassa & 6 & 7 \\
Cabo Delgado & 16 & 6 \\
Nampula & 24 & 26 \\
Zambezia & 15 & 34 \\
Tete & 8 & 10 \\
Manica & 5 & 10 \\
Sofala & 4 & 17 \\
Imhambane & 13 & 4 \\
Gaza & 16 & 0 \\
Maputo Province & 12 & 1 \\
Maputo City & 14 & 2 \\
Total & 133 & 117
\end{tabular}

In the provinces of Cabo Delgado, Niassa, Inhambane, Maputo Province and Maputo City, Frelimo secured twice as many seats as Renamo. This was reversed in the provinces of Zambezia, Manica and Sofala. In the remainder of the provinces, the two parties obtained a similar number of votes, although Renamo-UE obtained more seats than Frelimo.

The Uniao Democratica (UD) which had been the third political force in the AR in 1994, obtained only $1.5 \%$ of the votes in 1999 and therefore was unable to participate in Parliament. 
Palmo, which had been part of the UD in 1994 but had subsequently left the coalition, took $2.5 \%$ of the votes.

In the 1994 election, Frelimo had 129 deputies in the AR. This number increased to 133 in 1999 and in effect, meant that opposition representation in the AR decreased. However, Renamo-UE managed to obtain 117 seats (Renamo obtained 112 in 1994) out of a total of 250 seats. Seventeen of these deputies were from the smaller parties that had united with Renamo.

The results affected both the number of seats held by the political parties as well as the composition of their lists. This was obvious in the lists presented to the CNE. For example, Mr Abdul Carimo, the former first Vice-President of the AR for Frelimo, did not appear on the list. This was because he was 20th on the electoral list in Zambezia where Frelimo only managed to elect 15 deputies. The same situation applied to a lawyer from Renamo, Mr Jafar Gulano Jafar, the former spokesperson for Judicial Affairs, who was fourth on the electoral list in Maputo City where Renamo-UE had two deputies elected.

\section{Post-electoral Disputes}

Before the release of the results by the CNE, the Renamo-Electoral Union declared that they would not accept any results that awarded a victory to Chissano and Frelimo. When the CNE declared Chissano and Frelimo victorious on 22 December 1999, Renamo-UE declared the results fraudulent and submitted a claim to the Supreme Court for a re-count of the ballots.

Although Renamo-UE did not divulge the details of its claim, Mr Maximo Dias, lawyer and President of Monamo, one of the parties united with Renamo, stated in an interview with Metical on 24 December 1999, that the Renamo-UE's objections were as follows:

- the processing of the results at the CNE was done on the basis of computer disks from the provincial electoral circles whereas it should have been done on the basis of the data from the registers and respective editions;

- the computer disks in question did not accurately reflect the number of registers and editions and a comparative analysis shows large discrepancies between the two;

- 938 editions in the presidential election and 1170 in the legislative election were not considered in the final count. In the presidential election this represented approximately 700000 votes, including abstentions, blank and spoilt votes. In the legislative elections, this represented 800000 votes. This could have altered the overall results of the elections, given that the difference between Chissano and Dhlakama was 205000 in favour of the declared winner; and

- the re-qualification of the spoilt votes was not completed and valid votes drawn from those which had been considered spoilt were not taken into account. This increased the number of abstentions to more than 30\%, but that did not reflect the reality of the situation. The electoral bodies themselves had declared that the abstention could not be higher than $25 \%$.

Renamo requested the results of the election be nullified and a re-count of the ballots be held. The Supreme Court responded in detail to each of the arguments raised by Renamo. It declared that the documentation provided by Renamo and the reasons contained in it were insufficient to nullify the election results or to justify a re-count of the ballots. For instance, with regard to the use of computer disks from the provincial commissions, which Renamo considered illegal and fraudulent, the court responded by stating that: 
in order to protect the data, the CNE had decided to use - not computer disks but compact discs, also called CD-Rom (Read only Memory), which were used in the transportation and reproduction of data from various electoral circles. By using electronic supports instead of registers and editions, the CNE was still acting legally, according to the norms established by the Law and its own deliberations. The electronic supports also allow comparison of the registers and editions, provided that they are faithful copies of the originals.

The Supreme Court recognised the fact that the remaining editions had needed to be processed but it rejected the figures suggested by the coalition. According to the STAE, 7772 and 7595 editions were processed in the centre for the presidential and the legislative elections respectively. Five hundred and fifty and 727 editions respectively remained unprocessed. The court noted that these editions encompassed the provinces of Manica and Maputo-City and that it had been impossible to process them. This was because the data contained such errors as:

- missing codes of the electoral assembly;

- missing numbers of votes in the ballot boxes;

- no indication of the numbers of votes per candidate, party or coalition;

- non-indication of valid votes;

- discrepancies between the number of the valid votes, spoilt votes, blank votes and the total number of ballots;

- editions and registers with erasures and unclear alterations; and

- editions processed without saving the data on computer.

The Supreme Court stated that:

The irregularities were so obvious that there was no claim from any candidate or party for the rejection of any of them. This represents $6.61 \%$ and $8.74 \%$ of the electoral assemblies respectively in the presidential and legislative elections. If we consider the maximum of 634 voters per register and the participation rate of $69.51 \%$, the total number of voters would be 3777 773; not 900000 as alleged by the contender, including blank and spoilt votes, which represent about $10 \%$.

In response to the re-qualification and validation of the spoilt votes and their redistribution to the candidates, the court stated that these votes had been re-qualified and distributed to the candidates, political parties and coalitions.

The court estimated the number of spoilt votes in the presidential election to be 194 345; of which 58262 were re-qualified and redistributed as follows: Dhlakama, 30349 votes, and Chissano, 27913 votes. The results were thus validated and announced by the CNE on 4 January 2000.

Renamo-UE threatened to install parallel governments in the provinces where it won a majority of parliamentary seats, namely, Manica, Nampula, Sofala, Tete and Zambezia.

A number of the smaller political parties in the Renamo-UE coalition did not support the parliamentary boycott. On 14 January 2000, Renamo reversed its boycott stance and all parliamentarians took their seats during the first sitting of the new Parliament.

On 15 January 2000, Chissano was inaugurated for a second and last mandate as the president of the Republic in the presence of Dr Mario Mangaze, the president of the Supreme Court. Mr Joachim Mulembwe was re-elected president of the Assembly of the Republic. 


\section{Conclusion}

Mozambique's second general elections were considered by local and international observers to be a success. At one level, the 1999 Mozambican elections demonstrate general compliance with due process and the use of formal channels for complaints. After all, Renamo was fully within its rights to submit its appeal for a re-count of the votes to the Supreme Court. However, interim statements by Renamo officials that Frelimo had 'stolen' the elections, that the party would make Mozambique 'ungovernable' and that the Supreme Court lacked independence, serve notice that Mozambique's path to democracy continues to require careful navigation.

Frelimo remains intransigent about its claim to appoint all provincial governors as the majority party at national level. This constitutional issue poses a major obstacle to continued reconciliation in Mozambique. After all, Frelimo is rightly suspicious that Renamo governors might be tempted to play the same game of working with Frelimo inside government while threatening to undermine it, as has emerged was often the case in the CNE. Frelimo refuses to give in to Renamo's demands in this regard, particularly because a hard-fought constitutional settlement was lost immediately before the elections when Renamo refused to honour its commitments, calculating that it stood to win more power through the ballot box.

\section{Acknowledgements}

The author wishes to thank David Pottie, Denis Kadima and the Electoral Commissions Forum of SADC Countries. 